\title{
DENGUE
}

\section{MUSCLE BIOPSY FINDINGS IN 15 PATIENTS}

\author{
S.M.F. MALHEIROS*, A.S.B. OLIVEIRA*, B. SCHMIDT** J.G. CAMARGO LIMA*,
} A.A. GABBAI*

\begin{abstract}
SUMMARY - Dengue is known to produce a syndrome involving muscles, tendons and folnts. The hallmark of this syndrome is severe myalgia but includes fever, cutaneous rash, and headache. The neuromuscular aspects of this infection are outlined only in isolated reports, and the muscle histopathological features during myalgia have not been described. In order to ascertain the actual neuromuscular involvement in dengue and better comprehend the histological nature of myalgia, we performed a clinical and neurological evaluation, a serum CPK level and a muscle biopsy (with histochemistry) in 15 patients (4 maies), median age 23 years (range 14-47) with classic dengue fever, serologically confirmed, during the brazillan dengue epidemics from September 1986 to March 1987. All patients had a history of lever, headache and severe myalgla. Upon examination 4 had a cutaneous rash, 3 had fever, and 3 a small hepatomegaly. The neurological examination was unremarkable in all and inciuded a manual muscle test. CPK was mildly elevated in only 3 patients Muscle biopsy revealed a light to moderate perivascular mononuclear infiltrate in 12 patients and lipld accumulation in 11. Mild mitochondrial proliferation was seen in 3, few central nuclei in 3, rare foci of myonecrosis in 3 , and 2 patients had type grouping. Dengue in our patients, produced myalgia but no detectable muscle weakness or other neuromuscular involvement. The main histopathological correlation with myalgia seems to be a perivascular mononuclear Infiltrate and lipid accumulation.
\end{abstract}

KEY WORDS: dengue, muscle, myalgia.

\section{Dengue: achados de biópsia muscular em 15 pacientes}

RESUMO - A síndrome clínica produzida pelo vírus da dengue, inclui febre, exantema, cefaléia e especialmente mialgia. Entretanto, as possiveis alteraçóes morfológicas do músculo esquelético, eventualmente relacionadas com a mialgia, ainda não haviam sido estudadas em seres humanos com dengue. Nosso objetivo foi estudar o substrato, anátomo-patológico da mialgia nesses pacientes. Foram avaliados 15 pacientes com diagnóstico de dengue, forma clássica, com idades varlando de 14 a 47 anos (medianta de 23 anos), sendo 4 do sexo masculíno e 11 do sexo feminino, através de exame clínico e neurológico, exames laboratorlals e biópsla muscular com histoquímica, durante a epidemia de dengue em Alagoas, em 1987. Todos as pacientes apresentavam história de cefaléla, febre e mialgia intensa, sem fraqueza muscular. Ao exame clínico observou-se exantema em 4 pacientes, febre em 3 e discreta hepatomegalia em 3. $O$ exame neurológico fol normal em todos e a enzima CK sérica estava pouco elevada em 3 pacientes. A biópsia muscular revelou discreto infiltrado inflamatorio mononuclear perivascular em 12 pacientes, acúmulo lipídico em 11, predomináncia de fibras do tipo I em 6, raros focos de necrose em 3, proliferação mitocondrial em 3, centralizaçáo nuclear em 3 e "type grouping" em 2. As alteraçōes majs frequentemente observadas na biópsia muscular, infiltrado inflamatório perivascular e acúmulo lípídico, podem estar relacionadas com a mialgia.

PALAVRAS-CHAVE: dengue, músculo, mialgia.

*Department of Neurology and **Department of Pathology, Escola Paulista de Medicina, Sao Paulo. Aceite: 08-novembro-1992.

Dr. Acary S.B. Oliveira - Department of Neurology, Escola Paulista de Medicina - Rua Botucatu 720 - 04023-900 Săo Paulo SP - Brasil. 
Dengue, caused by an arthropod-borne RNA virus 6.19, is still a major public health problem in tropical areas, mainly in Southeast Asia, the Pacific region, and more recently, in the Americas 5,8,22. Myalgia is a characteristic symptom of dengue fever, and is also frequent in other viral infections 14,16,18 but its pathogenesis still remains poorly understood 14,16. There are isolated experimental reports about the pathological findings in skeletal muscle in dengue 1,20 , but we have been unable to find any pathological study of skeletal muscle in humans with myalgia and dengue fever.

This report describes the skeletal muscle histological abnormalities in 15 patients with dengue fever and severe myalgia, as an attempt to better understand the histological nature of that symptom.

\section{PATIENTS AND METHODS}

We studied 15 patients with dengue fever, 4 males, 11 females, median age 23 years (range 14 to 47 years), during an epldemic of ciassic dengue fever from September 1986 to March 1987, in the city of Maceio, state of Alagoas, Brazil. The diagnasis was based on epidemlological data, clinical manifestations and confirmed by hemagglutination inhibition method (positive in all 15 patients), IgM. antlbody detection by Mac ELISA (positive in all 8 studied) and virus isolation (in one patient studied).

All patients had a history of fever, headache and severe myailgia. Two patients complained also of arthralgia. All patients were submitted to cínical and neurological examinations including a manual muscle test 2. Table 1 summarizes the age, sex, clinical signs, neurological examination and duration of symptoms before biopsy. Classic dengue fever is typically an ecute febrile illness with rash, headache, retro-orbital pain, arthralgia and severe myalgia 13,21.

Blood tests that inciuded complete blood count, sodium, potassium, lactic dehydrogenase, creatine kinase (CK), pyruvic transaminase (SGPT), and glutamic transaminase (SGOT) were unremarkable with the exception of three patients (patients 4,7 and 13) that showed a slight increase of serum CK (2 times normal). Urinalysis and EKG were normal in all patients. Electromyography was not done.

Muscle biopsies were performed in the left superficial deltoid muscle on all patients. The biopsy technique and muscle processing used are all well established and have been described elsewhere 9. All biopsies were stained with H\&E, modifled Gomori, PAS, Sudan red, ATPases 9.4, 4.3 and 4.6, NADH and SDH.

\section{RESULTS}

All blopsies presented normal staining to PAS and NADH. The histopathological findings are summarized in Table 2.

A light to moderate perivascular mononuclear infiltrate was found in 12 patients (HL\&E) (Fig. 1). The infiltrate consisted of mononuclear cells around small vessels malnly in the perimysium. The infitrate was predominant in the perivascular space and did not invade muscle fibers. In rare occasions the infiltrate was also seen in the endomysium mainly around small vessels (Fig. 2.) Iren when moderate the infiltrate did not invade or disrupt the ressel walls. The infiltrate was found in 11 patients within 2 to 8 days of symptomatology; only one patient had a 14 day history of dengue fever.

Eleven biopsies presented with a mild lipid accumulation (Sudan red) diffusely located in at least $50 \%$ of the fibers. Nine biopsies showed both perivascular infiltrates and lipid raccumulation.

Other findings included mitochondrial proliferation located mainly in the periphery of the fibers in 3 blopsies, central nuclei in 3 , rare foci of necrosis in 3 , and type grouping in 2. These latter findings were always associated with either perivascular infiltrates, lipid accumulation or both (Table 2).

Except for one patient (with a 3 day history) that presented a normal muscle biopsy, 11 patients showed at least two different abnormalities in their blopstes. 
Table 1. Clinical presentation of patients with classical dengue fever.

\begin{tabular}{|c|c||c||c|c|c|}
\hline Case & Age & Sex & $\begin{array}{c}\text { Clinical } \\
\text { Signs }\end{array}$ & $\begin{array}{c}\text { Neurological } \\
\text { Examination }\end{array}$ & $\begin{array}{c}\text { Duration of } \\
\text { Symptoms (days) }\end{array}$ \\
\hline 1 & 18 & $f$ & & normal & 10 \\
\hline 2 & 36 & $m$ & & normal & 08 \\
\hline 3 & 15 & $f$ & $\begin{array}{c}\text { rash, } \\
\text { nepatomegaly }\end{array}$ & normal & 04 \\
\hline 4 & 21 & $f$ & & normal & 08 \\
\hline 5 & 47 & $f$ & fever & normal & 03 \\
\hline 6 & 34 & $f$ & & normal & 02 \\
\hline 7 & 47 & $m$ & nepatomegaly & normal & 07 \\
\hline 8 & 20 & $m$ & rash & normal & 03 \\
\hline 9 & 27 & $f$ & & normal & 02 \\
\hline 10 & 23 & $f$ & & normal & 14 \\
\hline 11 & 12 & $f$ & rever & normal & 02 \\
\hline 12 & 18 & $f$ & fever & normal & 08 \\
\hline 13 & 42 & $f$ & $\begin{array}{r}\text { rash, } \\
\text { nepatomegaly }\end{array}$ & normal & 07 \\
\hline 14 & 23 & $f$ & & normal & 08 \\
\hline 15 & 14 & $m$ & rash & normal & 06 \\
\hline
\end{tabular}

Table 2. Muscle histopathological findings in patients with classical dengue fever.

\begin{tabular}{|c|c|c|c|c|c|c|}
\hline Case & PMI & $\mathbf{L A}^{*}$ & MPO & $\mathrm{CN}^{\infty}$ & N8 & TG. \\
\hline 1 & & + & & & & \\
\hline 2 & + & & & & & \\
\hline 3 & + & + & & & & \\
\hline 4 & + & + & & & & \\
\hline 5 & + & + & & & & \\
\hline 6 & + & + & & & & + \\
\hline 7 & + & 4 & & & + & \\
\hline 8 & & & & & & \\
\hline 9 & + & + & + & & & \\
\hline 10 & + & & & & & \\
\hline 11 & + & + & & & + & \\
\hline 12 & + & & & + & & \\
\hline 13 & & + & + & + & & \\
\hline 14 & + & + & + & + & + & \\
\hline 15 & + & + & & & & + \\
\hline
\end{tabular}

- perivascular mononuclear infiltrate

- lipid accumulation

- mitochondrial proliferation

- central núclei

5 necrosis

- type grouping 


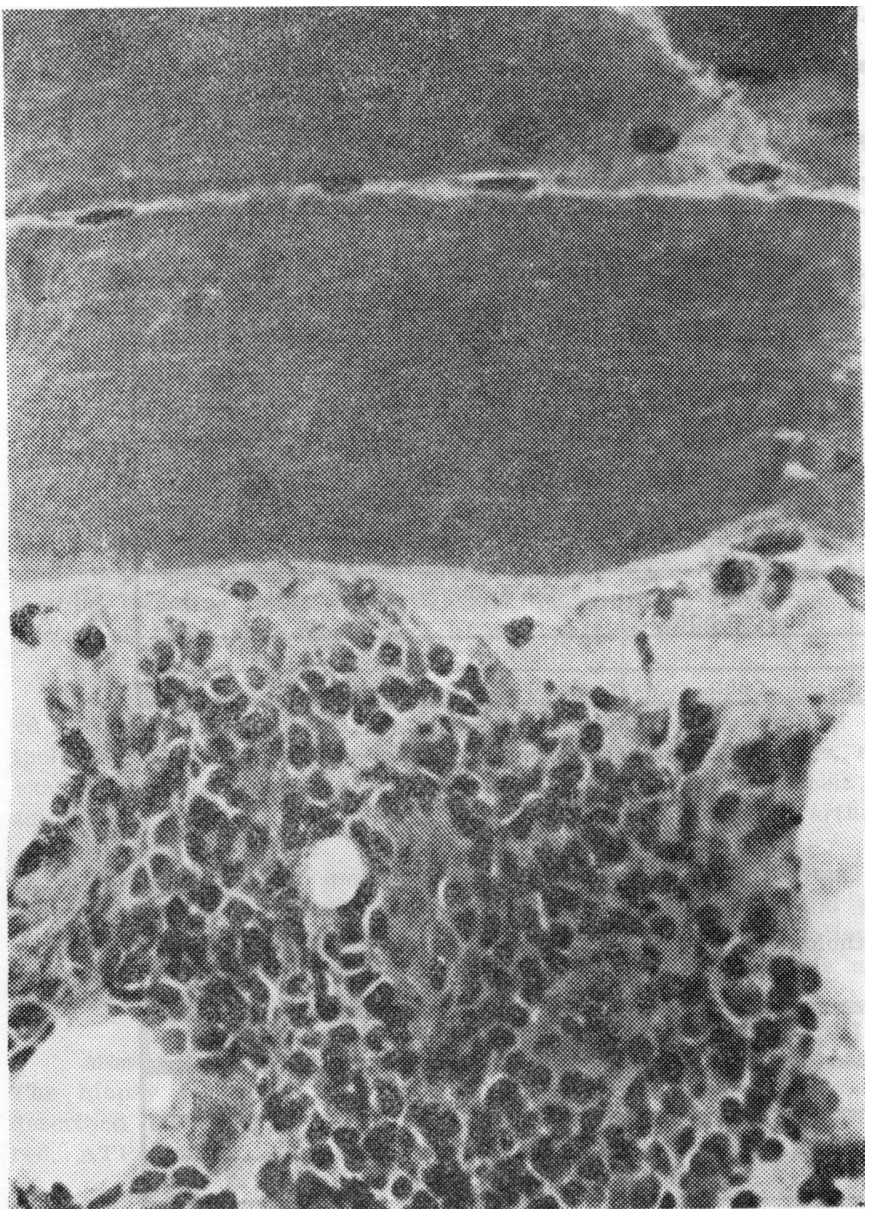

Fig. 1. A collection of mononuclear inflammatory cells around small blood vessels In the perimysium. (H\&F, $\mathrm{x500)}$ ).

\section{COMMENTS}

To our knowledge this is the first report of the muscle histopathological features that accompany classic dengue fever. It is intriguing to note that we have not found any example of true myositis in spite of the fact that myositis, sometimes associated with perivascular inflammatory infiltrates, seems to be the basic histological abnormality found in skeletal muscle of animals and humans infected with other viruses like influenza and coxsackie 11,12,17.

Agarawal et al.1 have studied metabolic changes in skeletal muscle in mice nfter intracerebral inoculation of Dengue virus type 2 but do not describe histological muscle abnormalities. Nath et al.20 have reported the ultrastructural alterations in skeletal muscle of dengue infected mice showing destruction of myofibrils and sarcoplasmic reticulum, swelling of mitochondria, glycogen accumulation and the demonstration of virus-like particles in the perinuclear zone and cytoplasm. They also do not describe any histological light microscopy abnormalities.

Our findings showed perivascular mononuclear infiltrates (but no myositis) and lipid accumulation (but not glycogen). Perivascular infiltrates were described in the CNS 7, soft tissue 4 and other organs 21 in post mortem studies of patients with dengue shock syndrome but not in the skin in dengue hemorrhagic fever 24 . 


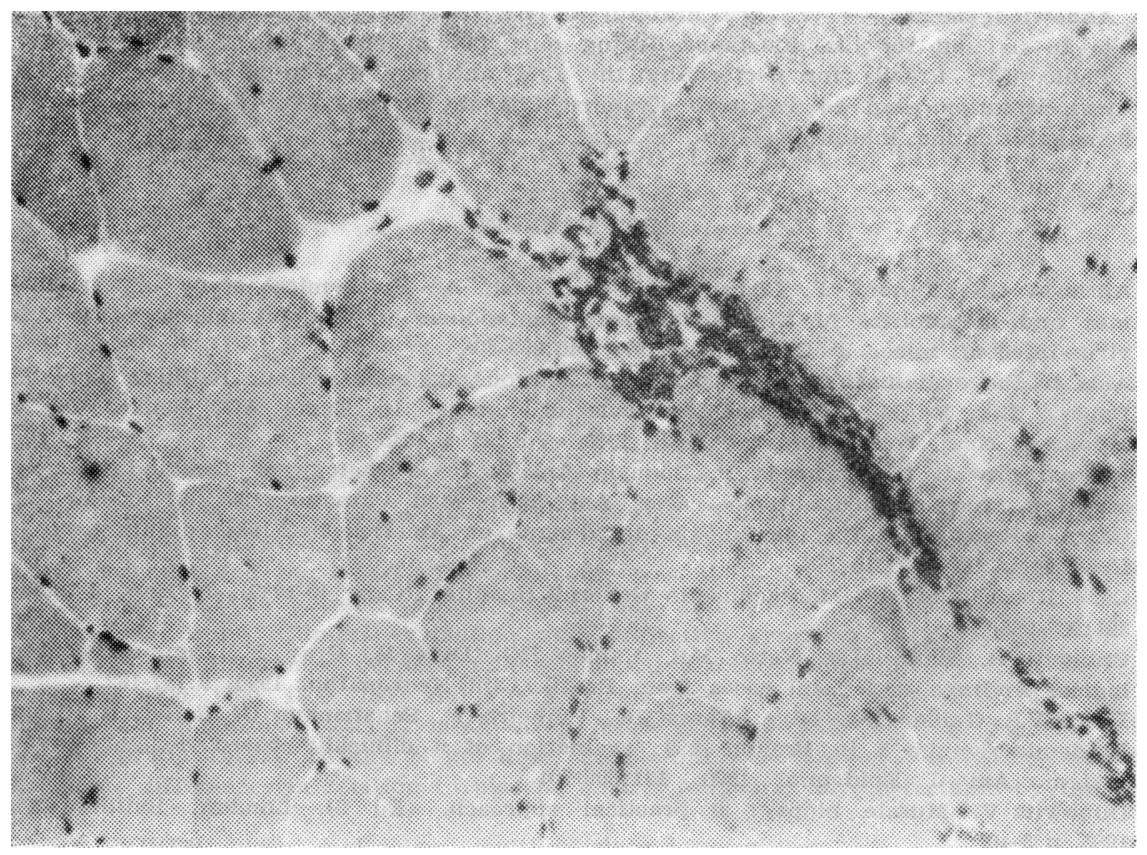

Fig. 2. Mononuclear cell infiltrates in the endomysium predominantly located around small blood vessiels. (H\&IF, $\mathbf{3} 360$ ).

The perivascular infiltrate found in 12 of our 15 patients may be related to the pathogenesis of myalgia by producing ischaemic or metabolic changes $1.16,23$ or even by local release of short-acting chemical mediators that could likely be effectors of pain 16,23. We found lipid accumulation in 11 patients and 9 of them also showed perivascular infiltrates. The lipid accumulation could be the consequence of an ischaemic phenomenon related to the perivascular abnormality.

The mitochondrial proliferation found in three of our patients and the mitochondrial changes found by Nath et al.20 in their ultrastructural study of skeletal muscle in mice may also reflect an abnormality in the oxidative meta. bolic pathway and might suggest that myalgia is due to metabolic changes 1,16,23.

Three of our patients who presented with perivascular infiltrates and lipid accumulation, also showed some foci of necrosis. Although these patients did not complain of a more severe myalgia than the others, muscle necrosis is known to produce pain 16,23. One of these patients also showed a mildly elevated serum CK. Hence it is possible that the other two patients with elevated CK and the others without necrosis and CK abnormalities may have a metabolic muscle involvement severe enough to produce pain but not enough to produce necrosis or CK elevation.

As an indirect evidence of altered sarcoplasmic homeostasis. possibly also reflecting the metabolic abnormalities already cited, three of our patients showed central nuclei 10.

We have been unable to explain the reason for the type grouping found in 2 of our 15 patients. In the superficial deltoid muscle the ATPase-checkboard pattern rarely varies 3,15 and these patients did not show any clinical evidence of peripheral nerve involvement.

New studies are needed to analyze the vascular involvement in muscle in the genesis of myalgia. Immunohistochemical and in situ hybridization techniques will help define the presence of the virus in cells around vessels and in the muscle and determine the nature of the mononuclear cells involved. 


\begin{abstract}
Aknowledgements - We are grateful to Dr. Fernando Lira Neto for referring the patients to us and for his assistance during our stay in Maceló, to Instituto Adolfo Lutz (São Paulo, SP, Brasil) for performing the IgM antibody detections by Mac ELISA and the virusi isolation, and to Instituto Evandro Chagas (Belém, PA, Brasil) for performing the hemagglutination inhibition tests.
\end{abstract}

\title{
REFERENCES
}

1. Agrawal DK, Tandon P, Chaturvedi UC, Kumar A. Biochemical study of ceitain enzymes and metabolites of the carbohydrate metabolism in skeletal muscle of the dengue virus-infected mice. J Gen Virol 1978, 40:399-408.

2. Alds to the examination of the peripheral nervous system. London: Bailliere Tindall, 1986.

3. Banker BQ, Engel AG. Basic reactions of muscle. In Engel AG, Banker BQ (eds): Myology. New York: MeGraw Hill, 1986, Vol 1, p 845-907.

4. Bhamarapravati N, Tuchinda $P$, Boonyapaknavik U. Pathology of Thailand haemorrhagic fever: a study of 100 autopsy cases. Ann Trop Med Parasitor: 1967, 61:500-510.

5. Carrada-Bravo T. La epidemiologia del dengue en America 1982-1984: quinta parte. Salud Publ Mex 1987, 29:15-25.

6. Case Records of the Massachusetts General Hospital (Case 40-1989). N Engl J Med 1989, $321: 957-965$.

7. Chimelli L, Hahn MD, Netto MB, Ramas RG, Dias M, Gray F. Dengue: neuropathological findings in 5 fatal cases from Brazil. Clin Neuropathol 1990, 9:157-162.

8. Dietz VJ, Gubler DJ, Rigau-Perez JG, Pinheiro F, Schatzmayr G, Bailey R, Gunn RA. Epidemic dengue 1 in Brazil, 1996: evaluation of a clinically based dengue surveillance system. Am J Epidemiol 1990, 131:693-701.

9. Dubowitz V. Muscle biopsy: a practical approach. (Ed 2). London: Bailliere Tindall, 1985, p 3-40.

10. Engel AG, Banker BQ. Ultrastructural changes in diseased muscle. In Engel AG, Bankcr BQ (eds): Myology. New York: McGraw Hill, 1986, Vol 1, p s09-1043.

11. Farrel MK. Partin JC, Boue KE. Epidemic influenza myopathy in Cincinnati in 1977. $J$ Pediatr 1980, 96:545-551.

12. Gamboa ET, Eastwood AB, ays AP, Maxwell J, Penn AS. Isolation of influenza virus from muscle in myoglobinuric polymyositis. Neurology 1979, 29:1323-1335.

13. Haistead SB. Dengue haemorrhagic fever: a public health problem and a field of research. Bull WO 1980, 58:1-21.

14. Hays AP, Gamboa ET. Acute viral myositis. In Engel AG, Banker BQ (eds): Myology. New York: 1986, Vol 2, p 1439-1466.

15. Johnson MA, Polgar J, Leightman D, Pippelton D. Data on the distribution of fiber types in thirty-six human muscles: an autopsy study. J Neurol Sci 1973, 18:111-129.

16. Layzer RB. Muscle pain, cramps and fatigue. In Fingel AG, Banker BQ (eds): Myology. New York: 1986, Vol. 2, 1907-1921.

17. Lepine $P$, Desse $G$, Sautter V. Biopsies musculaires avec examen histologique et isolement du virus coxsackie chex l'homme atteint de myalgie epidemique (maladie de Bornholm). Bull Acad Nation Med 1952, 136:66-69.

18. Mastaglia FL, Ojeda UJ. Inflammatory myopathies: part 1. Ann Neurol 1985, 17:215-227.

19. Murphy FA, Kingsbury DW. Flaviviruses. In Fields BN et al. (eds): Virology Ed 2. New York: Raven Press, 1990, Vol 1, p 763-814.

20. Nath P, Agrawal DK, Mehrotra RML. Ultrastructural changes in skeletal muscles in āengue virus-infected mice. J Pathol 1982, 136:301-305.

21. Organizacion Mundial de la Salud. Dengue hemorragico: diagnostico tratamiento y lucha. OMS, Ginlebra, 1987.

22. Pinheiro PF. Dengue in the Americas. Epidemiol Bull 1989, 10:1-8.

23. Roy EP, Gutmann L. Myalgia. In Riggs JE (eds): Neurologic Clinics: Muscle Disease. Philadelphia: W.B. Saunders, 1988, Vol 6, number 3, p 621-636.

24. Sahaphong S, Riengrojpitak S, Bhamarapravati $N$, Chirachariyavej $T$, Electron microscopic study of the vascular endotheltal cell in dengue hemorrhagic fever. Southeast Asian J Trop Med Pub Hlth 1980, 11:194-204. 